\title{
Forliksrådsfellen i internasjonale tvister
}

Av Josefin N. Engström

Artikkelen tar opp en prosessuell felle i tvisteloven som kan bli aktualisert i internasjonale sivilrettslige tvister. Innstilling av en sak i forliksrådet kan som ytterste konsekvens resultere $\mathrm{i}$ at en norsk part må gjennomføre rettsprosesser $\mathrm{i}$ utlandet, selv om søksmål ble tatt ut i Norge først. Problemstillingen har så langt blitt aktualisert i to norske saker, som vil bli gjennomgått i artikkelen. Formålet med artikkelen er å identifisere bakgrunnen for denne litispendensvirkning og å kommentere domstolenes tilnærming til problematikken. Artikkelen foreslår også endringer av gjeldende rett, som kan forhindre en forringelse av norske parters rettsstilling i internasjonale sivilrettslige tvister.

JOSEFIN N. ENGSTRÖM er født 1981 og har juridisk kandidateksamen fra Stockholms universitet (2010). Hun har erfaring som norsk og svensk advokat og er for tiden stipendiat ved Nordisk Institutt for Sjørett, Det juridiske fakultet, Universitetet i Oslo.

\section{Innledning ${ }^{1}$}

Denne artikkelen tar opp risikoen for forflytning av tvister til utlandet ved innstilling av en sak i forliksrådet.

I Norge må man som et utgangspunkt innom obligatorisk forliksrådsbehandling før en tvistesak kan bringes inn for tingretten. Forliksrådet har adgang til å innstille behandlingen av en sak etter skjønn, for eksempel om saken reiser kompliserte rettslige eller faktiske spørsmål som ikke vil kunne behandles forsvarlig med forliksrådets enkle behandlingsform. Ved innstilling i forliksrådet opphører litispendensvirkningen av saken. Denne virkningen ble innført med tvisteloven og følger av § 18-2 annet ledd, jf. § 6-1 annet ledd. Opphør av litispendensvirkningen kan få en uheldig konsekvens i sivilrettslige tvister med utenlandsk motpart. Problemstillingen angår de tilfeller der en norsk saksøker i henhold til tvisteloven må anlegge søksmålet for forliksrådet, og gjør dette, men hvor den utenlandske motparten parallelt, eller like etter at forliksrådet innstiller behandlingen av saken, anlegger søksmål om samme tvistegjenstand i et annet land. Forliksrådsfellen kan i slike tilfeller medføre en prosessforflytning fra Norge og forrang av utenlandsk verneting.

Det er en rekke tvistetyper som kan tenkes anlagt i flere land, etter forskjellige lands internasjonale privatrett. Dette gjelder for eksempel tvister etter kontrakter hvor partene befinner seg i forskjellige land, erstatningssaker hvor både handlingssted og virkningssted kan variere over et bredt spekter, mediesaker (artikler publisert på nett) og forskjellige familierettslige tvister etc.

Luganokonvensjonen sikrer at Norge og norske borgere omfattes av det samme regime for verneting

\footnotetext{
${ }^{1}$ Takk til professor Ivar Alvik og advokat Vidar Strømme for gode innspill og kommentarer.
} 
og for annerkjennelse og fullbyrdelse av dommer som gjelder i EU (også regler om litispendens). Det er imidlertid når tvistelovens regler om forliksrådets innstilling og opphør av litispendens blir aktualisert, at problematikken kan oppstå.

Formålet med denne artikkelen er å se nærmere på hvordan og hvorfor det problemet som er beskrevet ovenfor, har oppstått, samt diskutere alternativer til dagens ordning. Jeg vil gjøre dette ved først å gjennomgå gjeldende rettsregler om litispendens i internasjonale tvister og følgene av forliksrådets innstilling, jf. avsnitt 2, samt bakgrunnen for endringen som ble innført i forbindelse med tvisteloven, jf. avsnitt 3 . Jeg vil deretter foreta en gjennomgang av to norske rettssaker hvor denne problematikken har blitt vurdert, jf. avsnitt 4. Avslutningsvis vil jeg kommentere konsekvenser og problemstillinger ved gjeldende rett, jf. avsnitt 5.

\section{Litispendens i internasjonale tvister}

\subsection{Reglene i Luganokonvensjonen og tvisteloven}

Litispendens innebærer at det ikke kan anlegges søksmål om et krav som er søksmålsgjenstand i en annen verserende sak mellom de samme parter.

Begrunnelsen for reglene om litispendens er prosessøkonomiske hensyn og et ønske om å unngå motstridende dommer. ${ }^{2}$ Litispendens forutsetter identitet mellom tvistegjenstanden i de to sakene og at den formelle partsstillingen i de to sakene er den samme. Hva som utgjør én og samme tvistegjenstand i tilknytning til temaet litispendens, avgrenses på samme måte som etter reglene om negativ rettskraft. ${ }^{3}$ Virkningen av litispendens er at det senere $s \varnothing \mathrm{ksmålet} \mathrm{om} \mathrm{den} \mathrm{samme}$ tvistegjenstanden skal avvises av domstol nummer to. Domstolen skal håndheve litispendensregelen av eget initiativ - ex officio. ${ }^{4}$

Regler om litispendens i sivile og kommersielle tvister av internasjonal karakter er blant annet regulert i konvensjonen om domsmyndighet og fullbyrding av dommer i sivile og kommersielle saker (Luganokonvensjonen), ${ }^{5}$ jf. artikkel 27, 29 og 30. EU-rettslige fellesregler om domsmyndighet, anerkjennelse og fullbyrdelse av dommer i sivile og kommersielle tvister, inkludert litispendensregler, følger av Brüsselforordningen. ${ }^{6}$ Hensikten med Luganokonvensjonen er at Norge, Island og Sveits skal omfattes av det samme regime for verneting, anerkjennelse og fullbyrdelse av dommer som gjelder $\mathrm{i}$ EU. $^{7}$

${ }^{2}$ Tore Schei m.fl., Tvisteloven. Kommentarutgave Bind I, Universitetsforlaget, Oslo (2013): side 584.

${ }^{3}$ NOU 2001: 32 Rett på sak, bind B, side 874.

${ }^{4}$ Schei, side 586.

${ }^{5}$ Konvensjonen om domsmyndighet og om anerkjennelse og fullbyrdelse av dommer i sivile og kommersielle saker, vedtatt i Lugano 30. oktober 2007.

${ }^{6}$ Se artikkel 29-34 av Brüsselforordningen. Brüsselforordning 44/2001 er erstattet av forordning 1215/2012 som trådte i kraft 10. januar 2015. I henhold til reglene i den nye Brüsselforordningen har medlemsstater også adgang til å utsette eller avvise en sak som allerede er til behandling ved domstolene i en tredjestat (ikke medlemsstat).

Brüsselforordningen utgjør ikke norsk rett, men det er fremholdt fra akademisk hold at Luganokonvensjonen bør revideres i samsvar med endringene i Brüsselforordningen grunnet harmoniseringsformål og parallellisme. Dersom dette skjer, kan den nye litispendensregelen om behandling i tredjestater få relevans også for norske parter.

${ }^{7}$ Giuditta Cordero-Moss, «Revisjon av Luganokonvensjonen?», Lov og Rett, 2016 s. 1-2 (s. 1). 
Luganokonvensjonen er gjort til en del av norsk rett gjennom tvisteloven § 4-8, og er inkorporert i tvisteloven. ${ }^{8}$ Tvisteloven $\S 4-8$ må tolkes slik at konvensjonens bestemmelser i utgangspunktet har forrang ved eventuell motstrid med andre bestemmelser i tvisteloven.

EU er konvensjonspart til Luganokonvensjonen på vegne av alle EU-land, og Luganokonvensjonen gjelder dermed også mellom Norge og alle EU-landene, i tillegg til øvrige konvensjonsstater.

Litispendensvirkningen i henhold til Luganokonvensjonen følger av artikkel 27:

«1. Dersom søksmål som har samme tvistegjenstand, hviler på samme grunnlag, og som reises mellom de samme parter, anlegges ved domstoler i ulike konvensjonsstater, skal alle andre domstoler enn den som saken først er reist ved, av eget tiltak utsette forhandlingene til det er avgjort om den første domstol er kompetent.

2. Når det er avgjort at den første domstol er kompetent, skal alle andre domstoler erklære seg inkompetente til fordel for denne domstol.»

I henhold til Luganokonvensjonen artikkel $30 \mathrm{nr} .1$ er en sak reist ved det tidspunktet da det innledende prosesskriv i saken inngis til domstolen. ${ }^{9}$ Ved obligatorisk forliksrådsbehandling i Norge inntrer litispendensvirkning når forliksklagen er innkommet til forliksrådet. ${ }^{10}$

Forliksrådet må anses for å være en «domstol» i henhold til Luganokonvensjonen artikkel 27, jf. artikkel $62 .{ }^{11}$ Dette er lagt til grunn i tvistelovens forarbeider, og synes også å være lagt til grunn i norsk rettspraksis. ${ }^{12}$

Denne artikkelen omhandler vernetingsproblematikk knyttet til litispendensvirkningens opphør ved innstilling i forliksrådet. Det mest sentrale spørsmålet er således ved hvilket tidspunkt litispendensvirkningen opphører. Dette er ikke uttrykkelig regulert i konvensjonen. Fraværet av en uttrykkelig regulering i artikkel 27 og 30 av spørsmålet om en sak fortsatt verserer for nasjonale domstoler, tilsier at konvensjonen bør tolkes slik at nasjonale regler om opphør av litispendensvirkningen skal legges til grunn. ${ }^{13}$ Dette er også lagt til grunn av Høyesterett. ${ }^{14}$

${ }^{8}$ Lov 19. juni 2009 nr. 79 om endring av tvisteloven m.m.

${ }^{9}$ Hovedregelen følger av Luganokonvensjonen artikkel 30 nr. 1 og er ny i forhold til Luganokonvensjonen av 1988. Etter den gamle konvensjonen skulle det avgjøres i henhold til domstollandets rett når saken skulle anses for anlagt. Artikkel 30 harmoniserer således rettstilstanden mellom konvensjonsstatene hva gjelder litispendens.

${ }^{10}$ Dette følger av tvisteloven $\S 18-2(1)$.

${ }^{11}$ Luganokonvensjonens artikkel 62 stadfester: «I konvensjonen her omfatter uttrykket 'domstol' enhver myndighet som en konvensjonsstat har utpekt til å ha domsmyndighet i saker som hører under virkeområdet for konvensjonen her.»

${ }^{12}$ Se Ot.prp. nr. 51 (2004-2005) side 504: «Forliksrådene vil fortsatt bli å betrakte som en domstol. Men det er naturlig å markere at forliksrådene har en begrenset domsmyndighet i forhold til tingrett, lagmannsrett og Høyesterett. Det er gjort ved at forliksrådene er gitt en særskilt beskrivelse i annet ledd, der meklingsoppgaven er særlig framhevet [...]». Se også Rt. 2012 side 1404, hvor Høyesteretts ankeutvalg synes å legge til grunn at forliksrådet er en domstol i henhold til Luganokonvensjonen artikkel 27.

${ }^{13}$ Se note 107, siste avsnitt, i Norsk lovkommentar til Luganokonvensjonen artikkel 27 ved Henrik Bull.

${ }^{14}$ Rt. 2012 side 1404, avsnitt 24. 
Dette innebærer at det er tvistelovens bestemmelser som blir avgjørende når en norsk domstol skal vurdere hvorvidt litispendensvirkningen av en norsk forliksklage har opphørt etter Luganokonvensjonen artikkel 27.

Rettsreglene om litispendens i sivilrettslige tvister følger av tvisteloven kapittel 18. Litispendensvirkningen opphører som hovedregel når en avgjørelse blir rettskraftig, og blir da erstattet av de materielle rettskraftsvirkningene, så langt de rekker, jf. tvisteloven § 18-2 annet ledd. Dersom saken avvises eller heves, opphører litispendensvirkningen når avvisnings- eller hevingskjennelsen blir formelt rettskraftig.

Blir behandlingen av et krav innstilt i forliksrådet i henhold til § 6-11 første ledd, for eksempel på grunn av sakens kompleksitet, opphører litispendensvirkningen imidlertid umiddelbart. Dette følger av en utvidende tolkning av tvisteloven 18-2 annet ledd, jf. § 6-1 annet ledd, og vil bli nærmere redegjort for $\mathrm{i}$ avsnitt 3.1 nedenfor. Bakgrunnen for innføringen av denne ordningen vil bli nærmere drøftet i avsnitt 3.2 nedenfor.

Litispendensvirkningen kan også gjeninntre i noen tilfeller og hindre behandlingen av en senere anlagt sak, for eksempel ved fristoppfriskning av en allerede rettskraftig avgjørelse. ${ }^{15}$ Innvilges oppfriskning, vil saken stå i samme stilling som før rettskraften inntrådte, og en senere anlagt sak (anlagt $f ø r$ oppfriskningen ble gitt) skal da avvises. ${ }^{16}$ Slik gjeninntredelse av litispendensvirkningen gjelder imidlertid ikke dersom en sak blir brakt inn for tingretten umiddelbart etter forliksrådets innstilling, jf. avsnitt 4.1 nedenfor.

\section{Nærmere om opphør av litispendens ved innstilling i forliksrådet og endringer innført i forbindelse med tvisteloven}

\subsection{Forliksrådets innstilling og opphør av litispendens}

Forliksrådet er det laveste leddet i rettssystemet for sivile saker, og er obligatorisk førsteinstans for de fleste sivile saker, ikke minst for saker om formuesverdier når enten verdien av tvistegjenstanden er under $125000 \mathrm{kr}$, eller hvor partene ikke er bistått av advokat. ${ }^{17}$ Tvistemålsloven, i motsetning til tvisteloven, hadde et unntak som fanget opp deler av det problemet som er beskrevet ovenfor i avsnitt 1. Tvistemålsloven $\S 274$ første ledd nr. 2 oppstilte unntak fra obligatorisk forliksrådsbehandling når saksøkte eller dennes prosessfullmektige ikke hadde kjent bopel, arbeidssted eller forretningssted i Norge. Unntaket er ikke videreført i tvisteloven.

Forliksrådets dommere har ikke nødvendigvis juridisk fagkompetanse, men velges av kommunestyret for en periode på fire år, og forliksrådet har derfor også begrenset domsmyndighet. Dette er også bakgrunnen for at forliksrådene kan innstille behandlingen av en tvist i det tilfelle medlemmene anser saken lite egnet for behandling i forliksrådet. ${ }^{18}$ Slike uegnede saker kan for eksempel angå prosessuelle spørsmål om rettskraft, rettslig interesse og verneting i internasjonale forhold. ${ }^{19}$ Innstilling i forliksrådet medfører ikke automatisk at saken blir henvist til tingretten dersom

\footnotetext{
${ }^{15}$ Schei, side 587.

${ }^{16}$ Rt. 1979 side 1276.

${ }^{17}$ Tvisteloven $\S 6-2$.

${ }^{18}$ Tvisteloven $\S 6-11$.

${ }^{19}$ NOU 2001: 32 Rett på sak, bind A, side 298.
} 
én av partene forlanger det (slik rettsordningen var i henhold til tvistemålsloven § 294). For videre behandling av saken må den bringes inn på nytt for tingretten av en av partene.

I tvistemålsloven § 63 ble det uttrykkelig presisert når litispendensvirkningen inntrådte og når den opphørte, også i forbindelse med henvisning i forliksrådet. Litispendensvirkningen opphørte ikke automatisk, men ett år etter forliksrådets henvisning, med mindre stevning ble tatt ut. Det fremgikk av tredje ledd:

$\ll \S 63$.

Et krav er tvistgjenstand fra det tidspunkt, da forliksklage er kommet ind til forliksraadet eller stevning til retten. Reises et krav under saken, blir det tvistgjenstand fra det tidspunkt, da det fremsættes.

Kravet vedblir at være tvistgjenstand, indtil saken retskraftig er avgjort, hævet eller avvist.

Når et krav er henvist fra forliksrådet til retten, opphører det å være tvistegjenstand dersom stevning ikke er sendt til retten innen ett år fra henvisningsdagen.»

Tvisteloven trådte i kraft 1. januar 2008. Tvistemålsloven $\S 63$ tredje ledd er ikke videreført i tvisteloven. Dersom forliksrådet anser en sak å være uegnet for videre behandling i forliksrådet, henvises den ikke lenger til tingretten, men innstilles. Forliksrådets avgjørelse om å innstille behandlingen av en forliksklage kan ikke overprøves. ${ }^{20}$

« 6-11. Innstilling av saken

(1) Etter at tilsvar er mottatt, kan forliksrådet innstille behandlingen dersom det er lite sannsynlig at saken vil egne seg for videre behandling i forliksrådet.»

Tvisteloven angir ikke direkte hva som skjer med litispendensvirkningen når forliksrådet innstiller behandlingen i henhold til § 6-11 første ledd - slik tvistemålsloven gjorde. Dette siden innstilling faller utenfor ordlyden i tvisteloven § 18-2 annet ledd. At litispendensvirkningen opphører umiddelbart etter at forliksrådet har innstilt en klage, og ikke ett år fra henvisningsdagen som etter tvistemålsloven, er blitt klargjort gjennom rettspraksis ved en tolkning av lovens forarbeider og en utvidende tolkning av $§ 18-2$ annet ledd, jf. § 6-1 annet ledd. ${ }^{21}$ Forliksrådets beslutning om å innstille saken kan ikke angripes med rettsmidler. Den blir derfor rettskraftig straks, jf. § 19-14 første ledd. Virkningene av saksanlegget for forliksrådet opphører dermed. Dette blir utlest av § 18-2 annet ledd, som angir at litispendensvirkningen opphører når saken blir rettskraftig:

«Virkningen av saksanlegg etter § 18-2 opphører når saken er rettskraftig avgjort.»

Kravet for forliksrådet er dermed ikke lenger tvistegjenstand til hinder for nytt saksanlegg etter $\S 18-1$. Denne virkningen gjelder selv om sakens materielle sider kun har blitt innstilt og ikke rettskraftig avgjort. At ovennevnte bestemmelser i tvisteloven kommer til anvendelse på Forliksrådets virksomhet, følger av § 6-1 annet ledd.

\subsection{Bakgrunnen for endring av litispendensvirkningen ved forliksrådets innstilling} Tvistemålsutvalget var tydelig på at man ikke ønsket å videreføre litispendensvirkningen etter tvistemålsloven $§ 63$ tredje ledd som prosessuelt hinder i tvisteloven. Begrunnelsen for dette var at det

\footnotetext{
${ }^{20}$ Tvisteloven $\S 6-14$ annet ledd.

${ }^{21}$ Se Ot.prp. nr. 51 (2004-2005) side 384 og Rt. 2012 side 1404, avsnitt 28-29.
} 
ikke burde oppstilles et hinder for annen behandling av saken, for eksempel ved

Forbrukertvistutvalget, når saken ikke er avsluttet med rettskraftig avgjørelse ved dom eller forlik. ${ }^{22}$ Tvistemålsutvalgets forslag om ikke å videreføre regelen i sitt utkast til tvisteloven var således bevisst, og fremgår direkte av forarbeidene til tvisteloven:

«Det er ikke tatt med noen bestemmelse som viderefører tvistemålsloven § 63 tredje ledd i § 20-2. Tvistemålsutvalget har i drøftelsen av forliksrådets oppgaver og behandlingsregler konkludert med at mekling i forliksrådet bør gjøres valgfri. Det blir da ikke noe behov for en regel med slikt innhold som tvistemålsloven $\$ 66$ tredje ledd_[feilskrift for $§ 63$ tredje ledd] ettersom det da aldri av prosessuelle grunner vil vare påkrevet å begynne eventuelt nytt saksanlegg i forliksrådet.» ${ }^{23}$ (min kursivering)

Begrunnelsen for forslaget om ikke å videreføre regelen var altså motivert av at forliksrådsmekling ikke lenger skulle være obligatorisk i noen saker, og at regelen dermed ville bli unødvendig. Forslaget om valgfri forliksrådsmekling ble imidlertid ikke hensyntatt av departementet. I odelstingsproposisjonen valgte Justisdepartementet isteden å holde fast ved ordningen med forliksrådsmegling som obligatorisk førsteinstans, blant annet for å avlaste trykket på domstolene. ${ }^{24}$

«Krav om forliksrådsbehandling kan på denne bakgrunn ses som en forsterket plikt til å forsøke å løse tvisten i minnelighet. Departementet mener en slik forsterket meklingsplikt er nødvendig for å sikre en mulighet for rask og billig tvisteløsning og for å opprettholde forliksrådet som buffer mot tingretten. Det siste blir særlig aktuelt ved innføringen av småkravprosess, se kapittel 15.

Småkravprosessen senker søksmålsterskelen og forutsetter en $\varnothing$ king i antall småsaker til tingretten. Nettopp derfor mener departementet at småkravprosessen bør kombineres med pliktig forliksrådsmekling.» ${ }^{25}$ (min kursivering)

Tvisteloven viderefører derfor kravet om obligatorisk forliksrådsmekling i flere sivilrettslige tvister, jf. tvisteloven § 6-2. Departementet gjorde det klart at litispendensvirkningen likevel opphører ved innstilling av en sak i forliksrådet - dette fremgår av forarbeidene:

«Ved innstilling opphører litispendensvirkningen. Saken utgjør da ikke lenger noen tvistegjenstand, jf. § 18-1. Innstilling etter denne paragrafen vil imidlertid ikke bringe til opphør den virkning av forliksklagen som går ut på at foreldelse avbrytes i henhold til foreldelsesloven $\S 15$. Den virkningen vedvarer i ett år fra innstillingen, jf. § 18-3 annet ledd.» ${ }^{26}$

Eventuelle konsekvenser av at litispendensvirkningen opphører ved innstilling, ble imidlertid ikke drøftet i proposisjonen, og det er lite trolig at departementet tenkte gjennom de konsekvensene standpunktet ville ha for tvister med verneting i flere land. Jeg vil i denne sammenheng vise til to norske rettssaker som omhandler denne problematikken, og hvor gjeldende ordning har fătt store konsekvenser for de norske partene.

\section{To norske rettssaker}

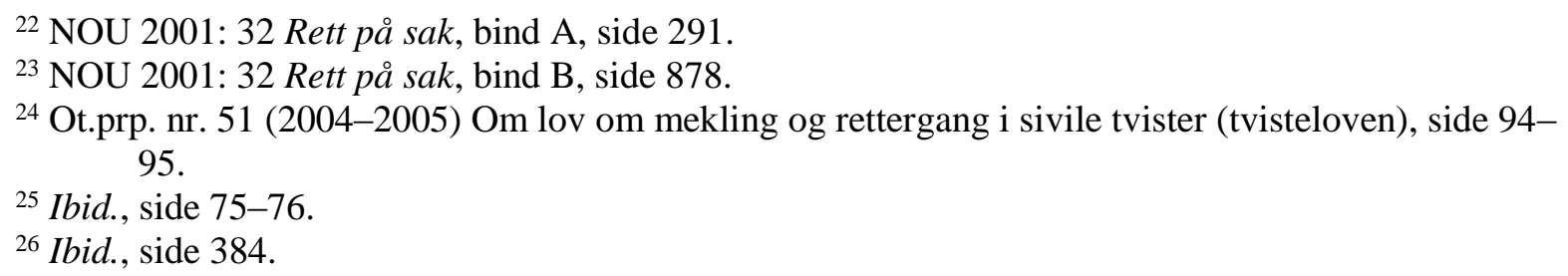




\subsection{Wikileaks-saken ${ }^{27}$}

Den første kjennelsen som omhandler den aktuelle problemstillingen, ble avgjort av Høyesterett i 2012. Kjennelsen har sin bakgrunn i et krav om erstatning fremmet av en tysk privatperson mot Aftenposten AS (heretter Aftenposten) på bakgrunn av angivelige injurier.

Den 2. oktober 2009 møtte direktøren for romfartsselskapet OHB-System, Berry Smutny, to amerikanske tjenestemenn til et uoffisielt lunsjmøte på den amerikanske ambassaden i Berlin. Det ble diskutert politikk og markedsstrategi, blant annet EUs prestisjetunge satellittprosjekt Galileo, som er ment å konkurrere med det amerikanske GPS-systemet. OHB-System bygger satellittene til EUs Galileo-prosjekt, og Smutny benyttet anledningen til å holde forbindelsene til amerikanerne varme, blant annet ved å uttale seg nedsettende om Galileo-prosjektet. Smutnys uttalelser ble nedtegnet og telegrafert til USAs utenriksdepartement i Washington - et telegram som menige Bradley Manning overleverte sammen med 250000 andre diplomatdokumenter til den internettbaserte varslingstjenesten Wikileaks i 2010. Diplomatposten ble kort tid deretter videreformidlet til noen av de største mediehusene verden over, herunder Aftenposten.

I januar 2011 slo Aftenposten opp at kostnadene for EUs Galileo-prosjekt ruset i vei, noe som ville medføre $\emptyset$ kte kostnader også for den norske stat. Smutnys kommentarer til de to amerikanske tjenestemennene i Berlin ble sitert - direktøren mente prosjektet var sløseri med penger. De norske artiklene ble også publisert på Aftenpostens nettsider. Nyheten spredte seg raskt til tyske medier, og et samlet styre i OHB-System mistet tilliten til sin egen direktør. Smutny måtte fratre sin stilling umiddelbart.

I april 2011 sendte Smutny krav om erstatning og varsel om stevning til Aftenposten. Aftenposten bestred kravet, men valgte også å ta ut forliksklage ved Oslo forliksråd 3. mai 2011, med krav om negativ fastsettelsesdom for at Smutny ikke hadde noe erstatningskrav mot selskapet. Forliksklagen var begrunnet i prosessrisikoen som følger av å gjennomføre en mediesak i utlandet, selv om artiklene var publisert på norsk.

Den 10. november 2011 innstilte forliksrådet behandlingen av saken fordi den ikke egnet seg for videre behandling i forliksrådet. Forliksrådets beslutning ble mottatt per post 17. november 2011 og skulle regnes som forkynt 18. november 2011. Ved stevning 17. november 2011 brakte Aftenposten saken inn for Oslo tingrett.

Den 12. juni 2011 hadde imidlertid Smutny tatt ut søksmål om samme tvistegjenstand mot Aftenposten ved en tysk domstol - Landgericht Köln. På dette tidspunktet var Aftenpostens forliksklage til behandling i forliksrådet. Ved Oslo tingretts behandling ble imidlertid Aftenpostens sak i Norge stanset. Oslo tingrett kom til at Smutnys søksmål ved Landgericht Köln hadde fått forrang etter Luganokonvensjonen artikkel 27. Dette siden litispendensvirkningen i henhold til tvisteloven opphører umiddelbart ved forliksrådets innstilling, dvs. 10. november 2011. Smutnys søksmål av 12. juni 2011 ble dermed regnet for å ha innkommet først - ikke Aftenpostens forliksklage av 3. mai $2011 .^{28}$

${ }^{27}$ Rt. 2012 side 1404. For ordens skyld nevnes at undertegnede var én av prosessfullmektigene i denne saken.

${ }^{28}$ Oslo tingretts kjennelse (TOSLO-2011-187541) er ikke tilgjengelig på Lovdata. Se også Rt. 2012 side 1404, avsnitt 3-6. 
Borgarting lagmannsrett kom ved kjennelse av 27. juni $2012^{29}$ til samme resultat som Oslo tingrett. Aftenposten anket saken videre inn for norsk $\mathrm{H} \varnothing$ yesterett, men anken førte ikke frem. Høyesterett uttalte følgende om den konsekvens av tvistelovens nye ordning at litispendensvirkningen opphører ved innstilling i forliksrådet:

«Til tross for at departementet gikk inn for å beholde obligatorisk forliksrådsmegling, valgte det likevel bevisst ikke å videreføre bestemmelsen i tvistemålsloven $\S 63$ tredje ledd. Ankeutvalget viser her til det som ovenfor er gjengitt fra Ot.prp. nr. 51 (2004-2005), side 384.

Utvalget har på dette grunnlag kommet til at lagmannsretten har tolket tvisteloven § 18-1, jf. § 18-2 riktig når den har lagt til grunn at litispendensvirkningen av en forliksklage opphører når saksbehandlingen blir innstilt etter § 6-11. Hvorvidt dette er en god ordning, må bli opp til lovgiver å vurdere. Lagmannsretten har også tolket Lugano-konvensjonen artikkel 27 riktig når den har lagt til grunn at søksmålet for Landgericht Köln i forhold til denne bestemmelse må anses anlagt først, og at saksbehandlingen for Oslo tingrett må utsettes til den tyske domstolen har tatt stilling til sin kompetanse.» ${ }^{30}$ (min kursivering)

Selv om Aftenposten i realiteten var først ute med sitt søksmål, som måtte innom obligatorisk forliksrådsbehandling (fastsettelsess øksmål og motpart uten norsk prosessfullmektig), ble den tyske saken gitt forrang grunnet norske prosessregler og treg behandling av litispendenstvisten ved den tyske domstolen. Konsekvensen i den gjeldende sak ble at Aftenposten måtte gjennomføre tysk rettsprosess gjennom to rettsinstanser, før saken ble endelig avgjort til Aftenpostens favør av ankedomstolen i Köln.

Oslo tingrett, som hadde stanset saken i medhold av Luganokonvensjonen hevet saken etter at den var rettskraftig avgjort av tyske domstoler. Aftenposten, som ble pålagt sakskostnadene i den norske saken, anket tingrettens saksomkostningsoppgave, mens Smutny gjorde gjeldende at saken skulle vært avvist, ikke hevet. Saken ble endelig avgjort ved kjennelse av Høyesteretts ankeutvalg, som konkluderte med at forutsetningene for å ta saken til behandling aldri hadde vært oppfylt, og at resultatet da må bli avvisning siden heving forutsetter at prosessforutsetningene er bortfalt etter saksanlegget. ${ }^{31}$ Smutny ble tilkjent sakskostnader for alle instanser i Norge.

\subsection{Petromena-saken ${ }^{32}$}

Den andre kjennelsen jeg skal redegjøre for, er fra Borgarting lagmannsrett, ${ }^{33}$ og fulgte etter Høyesteretts avgjørelse i Wikileaks-saken. Tvisten gjaldt krav om erstatning etter konkurs fremmet av det norske riggselskapet Petromena ASA under konkurs (heretter Petromena) mot selskapets bank Deutsche Bank AG.

Petromena var et norsk riggselskap som drev med drift og eierskap av dypvannsrigger. Selskapet ble notert på Oslo Axess i 2007 og slått konkurs i 2009 - én av norgeshistoriens største. I forkant av konkursen hadde selskapets tre datterselskaper (som utgjorde tre dypvannsrigger) blitt satt under konkursbeskyttelse i New York.

\footnotetext{
${ }^{29}$ LB-2012-46035 (12-046035ASK-BORG/04).

${ }^{30}$ Rt. 2012 side 1404 , avsnitt 28-29.

${ }^{31}$ Rt. 2015 side 13 , avsnitt 31.

${ }^{32}$ Se for eksempel «Vil ha 20 milliarder fra Deutsche Bank», tilgjengelig på http://www.dn.no/nyheter/energi/2011/05/18/vil-ha-20-milliarder-fra-deutsche-bank, først publisert 18. mai 2011 på www.dn.no.

${ }^{33}$ LB-2013-76568 - RG-2013-1193.
} 
Deutsche Bank AG var også en av Petromenas største obligasjonseiere og eide 34 prosent av et obligasjonslån Petromena hadde utstedt i forbindelse med bygging av oljerigger i Singapore.

Deutsche Bank AG var involvert i overtaket av riggselskapets tre dypvannsrigger - som senere ble solgt på auksjon. Kun dager før overtakelsen av riggene solgte banken sine eierandeler $\mathrm{i}$ obligasjonslånet til Petromenas konkurrent Seadrill. Petromena hevdet at obligasjonene ble solgt til underpris, og at Deutsche Bank AG opptrådte grovt uaktsomt i forbindelse med konkursen. Petromena påstod videre at Deutsche Bank AG var erstatningsansvarlig for dårlig rådgiving, som resulterte $\mathrm{i}$ at Petromena gikk konkurs. Etter Petromenas syn ville selskapet unngått konkurs og omfattende tap dersom Deutsche Bank AG hadde fulgt opp sin oppgave som finansiell rådgiver og opptrådt lojalt. Deutsche Bank AG på sin side avviste alle påstander om illojalitet og mente at det ikke fantes grunnlag for et krav mot banken.

Petromena, under konkurs, tok ut forliksklage mot Deutsche Bank AG ved Oslo forliksråd 29. desember 2011 og krevde erstatning etter rettens skjønn oppad begrenset til 7,36 milliarder kroner, med tillegg av renter og omkostninger. Oslo forliksråd innstilte behandlingen av forliksklagen 20 . juni 2012.

Dagen etter, den 21. juni 2012, tok Deutsche Bank AG, London Branch, ut fastsettelsess $\varnothing$ ksmål for The High Court of Justice i London med påstand om ansvarsfrihet i forhold til Petromena. Det var bankens Londonfilial som hadde bistått i rådgivningen til Petromena.

Den 5. september 2012 tok Petromena ut stevning mot Deutsche Bank AG ved Oslo tingrett. Petromena hevdet å være uvitende om søksmålet i England, da dette angivelig ble forkynt til Petromena 21. september 2012. I tilsvaret til Oslo tingrett påsto Deutsche Bank AG prinsipalt saken avvist under henvisning til saken som verserte for The High Court of Justice i London. Det ble vist til Luganokonvensjonen artikkel 27. Etter ytterligere prosesskrivutveksling og muntlig forhandling stanset Oslo tingrett den norske saken ved kjennelse av 19. februar $2013^{34}$ - i påvente av endelig avgjørelse om den engelske domstolen var kompetent til å behandle søksmålet fra Deutsche Bank AGs engelske filial mot Petromena. Oslo tingrett viste til Høyesteretts kjennelse i Wikileaks-saken (Rt. 2012 side 1404) og la til grunn at litispendensvirkningen av saken faller bort når en forliksklage innstilles. Oslo tingrett konkluderte deretter med at den engelske saken ble reist først.

Petromena anket kjennelsen videre til Borgarting lagmannsrett, som i sin kjennelse av 11. september 2013 blant annet uttalte følgende om Høyesteretts tolkningsresultat i Rt. 2012 side 1404:

«I tvisteloven er systemet med henvisning til retten avløst av innstilling av forliksrådets behandling, og det er ikke lenger noen uttrykkelig regulering i loven av om kravet fortsetter å være tvistegjenstand etter at forliksrådet har innstilt behandlingen. Her har Høyesterett i Rt-2012-1404 pekt på klare uttalelser i forarbeidene om at kravet opphører å være tvistegjenstand ved innstillingen. I forarbeidene er forholdet til internasjonale tvister ikke vurdert, og det kan stilles spфrsmål ved om resultatet innebarer en god ordning. Høyesterett har vart klar over hvordan regelen slår ut $i$ internasjonale tvister, og har vurdert de innvendinger Petromena nå har anfort mot resultatet som følger av lovgivers regelendring gjennom vedtakelse av tvisteloven. Som påpekt $i$ Rt-2012-1404 er det opp til lovgiver å vurdere om resultatet innebarer en god regel. Sett i lys av de klare uttalelsene i forarbeidene, som Høyesterett har vurdert, finner lagmannsretten det lite tvilsomt at Høyesteretts tolkning av litispendensreglene fortsatt bør følges.» ${ }^{35}$ (min kursivering)

\footnotetext{
${ }^{34}$ Oslo tingretts kjennelse (TOSLO-2012-142818) er ikke tilgjengelig på Lovdata.

${ }^{35}$ LB-2013-76568 - RG-2013-1193, side 6.
} 
Litispendens-spørsmålet ble ikke prøvd videre. Petromenas anke over lagmannsrettens kjennelse ble forkastet 16. desember 2013 - Høyesterett la enstemmig til grunn at anken ikke kunne føre frem. ${ }^{36}$ Den engelske saken ble fremmet ved dom fra The High Court of Justice 14. oktober 2013. Etter anke fra Petromena ble vernetingsavgjørelsen opprettholdt av The Court of Appeal 18. mars 2015. The Supreme Court avgjorde 23. juli 2015 at Petromenas anke over the Court of Appeals avgjørelse skulle forkastes. Deutsche Bank AG nedla deretter nytt prosesskriv for tingretten 7. august $2015 \mathrm{om}$ at den norske saken endelig skulle avvises. Deutsche Bank AG fikk medhold av tingretten ved kjennelse av 28. oktober 2015. Petromena anket tingrettens kjennelse om avvisning, og lagmannsretten forkastet denne anken 13. mai 2016. ${ }^{37}$ Den norske saken var dermed endelig, og Deutsche Bank AG ble tilkjent sakskostnader for alle instanser i Norge. Hovedsaken mellom Petromena og Deutsche Bank AG verserer nå for engelske domstoler.

Det foreligger for $\varnothing y e b l i k k e t$ ikke noen lignende saker til behandling i det norske rettssystemet. Høyesteretts vurdering i Rt. 2012 side 1404 fastsetter således gjeldende rett hva gjelder litispendensvirkningens opphør ved forliksrådets innstilling i internasjonale tvister.

\section{Kommentarer til gjeldende rett}

\subsection{Internasjonal rettssikkerhetsproblematikk}

Jeg har i det foregående redegjort for hvordan opphør av litispendensvirkningen i henhold til norske prosessregler kan medføre at søksmål i andre land gis forrang - med det resultat at rettsprosesser må gjennomføres i utlandet selv når en norsk part i utgangspunktet anla sin sak i Norge først.

Konsekvensene er ikke like alvorlige dersom begge parter er norske. Dette siden eventuelt opphør av litispendensvirkningen ved forliksrådets innstilling som ytterste konsekvens kan medføre at motparten bringer saken inn for et annet norsk verneting. Problemstillingene som knytter seg til utenlandsk prosessrisiko, blir først aktualisert i en internasjonal tvist, og opph $\varnothing \mathrm{r}$ av litispendensvirkningen er derfor mest interessant å vurdere i et internasjonalt perspektiv. Som nevnt over er det også trolig at det nettopp er de internasjonale aspektene som ble forbigått av departementet i forbindelse med utarbeidelse av tvisteloven.

Som nevnt i innledningen er det en rekke tvistetyper som kan tenkes anlagt i flere land, etter forskjellige lands internasjonale privatrett. Dette gjelder for eksempel tvister etter kontrakter, erstatningssaker, mediesaker og forskjellige familierettslige tvister etc. Luganokonvensjonen avsnitt 2-6 regulerer valg av verneting mellom norske og europeiske motparter. Selv om de enkelte lands internasjonale privatrett, og konvensjoner, har tatt sikte på å redusere såkalt forum shopping, er det en anselig mengde saker hvor det $\mathrm{i}$ utgangspunktet kan foreligge flere verneting eller en valgfrihet knyttet til verneting. I erstatningssaker kan det for eksempel anlegges søksmål både på handlingsstedet (lex loci actus) og virkningsstedet (lex loci damni). ${ }^{38}$

I tillegg til verneting aktualiseres annen rettsvalgsproblematikk. Som hovedregel reguleres lovvalg og de materielle reglene som kommer til anvendelse i en tvist, av den internasjonale privatrett i det aktuelle land. I Norge er lovvalgsreglene i hovedsak ulovfestet på den internasjonale formuerettens

\footnotetext{
${ }^{36}$ HR-2013-2602-U.

${ }^{37}$ LB-2016-1351.

${ }^{38}$ Jf. blant annet tvisteloven $§ 4-5$ og Luganokonvensjonen artikkel 5 (3).
} 
område, mens Roma-konvensjonen ${ }^{39}$ og Roma I-forordningen ${ }^{40}$ regulerer lovvalg for kontraktsforpliktelser innen EU. Lovvalg for forpliktelser utenfor kontrakt reguleres innen EU av Roma II-forordningen. ${ }^{41}$ Forpliktelser som knytter seg til ærekrenkelser, er imidlertid unntatt fra Roma II-forordningen. Dette på bakgrunn av at hovedregelen i henhold til forordningen er at virkningsstedets rett (lex loci damni) skal legges til grunn - noe som ville skapt uforutsigbarhet for pressen. Dette ble imidlertid realiteten i Wikileaks-saken, nevnt over, hvor de tyske domstolene tillempet tysk rett på de materielle rettsspørsmålene i saken. ${ }^{42}$

Når det gjelder hvilke prosessregler saken skal behandles etter, er det alminnelige lovvalgsprinsipp etter internasjonal privatrett at domstollandets rett (lex fori) skal legges til grunn. Utgangspunktet er således at norske domstoler anvender norske prosessregler, osv. Dette medfører at vernetingets nasjonale rett blir lagt til grunn ved fordeling av sakskostnader - noe som resulterte i at Aftenposten ikke ble tilkjent full erstatning for sine sakskostnader etter å ha vunnet saken $\mathrm{i}$ ankedomstolen $\mathrm{i}$ Köln, ${ }^{43}$ jf. avsnitt 4.1 over. Det kan i noen land, særlig i henhold til angloamerikansk rett, også få betydning for foreldelsesspørsmålet - selv om Roma II-forordningen regulerer foreldelse etter lex loci deliciti-prinsippet. ${ }^{44}$ I tillegg blir rettsprosesser ofte gjennomført på domstollandets språk, hvilket kan innebære praktiske utfordringer knyttet til tolk, oversettelse av rettsdokumenter, behov for lokal prosessfullmektig etc.

Lovvalg innen EU fastsettes etter harmoniserte konvensjoner og forordninger som ikke er bindende for Norge, men som gir uttrykk for alminnelige anerkjente prinsipper innenfor internasjonal privatrett, og som også vektlegges i norsk rettspraksis. ${ }^{45}$ Men selv om valg av verneting ikke skal ha noe å si for lovvalget som regulerer tvistens materielle sider, så kan som nevnt over et utenlandsk verneting medføre nokså betydelige prosessuelle tilleggsdimensjoner som norske parter må forholde seg til, og som kan bli både tids- og kostnadskrevende.

Det innebærer også at norske parter med internasjonale engasjementer - og som derved forholder seg til utenlandske parter - står overfor et mer usikkert prosessforløp på grunn av

${ }^{39}$ Romakonvensjonen 19. juni 1980 om lovvalg i kontraktsforhold. Lovvalgsreglene i Romakonvensjonen gjelder for kontrakter inngått før 17. desember 2007.

${ }^{40}$ Forordning nr. 593/2008 om lovvalgsregler for kontraktsforpliktelser (Roma I-forordningen) ble vedtatt 17. juni 2008 og anvendes på kontrakter som er inngått etter 17. desember 2007.

${ }^{41}$ Forordning nr. 864/2007 om lovvalgsregler for forpliktelser utenfor kontrakt (Roma IIforordningen) ble vedtatt 11. juli $2007 \mathrm{og}$ anvendes fra 11. januar 2009.

${ }^{42}$ Se dom i ankesaken mellom Berry Smutny og Aftenposten fra Oberlandesgericht Köln, 15 U 53/13, avsnitt 42-44. Dommen er tilgjengelig på tysk på https://www.justiz.nrw.de/nrwe/olgs/koeln/j2013/15_U_53_13_Urteil_20131119.html

${ }^{43} \mathrm{Ibid}$., avsnitt 76. Samtlige krav fremsatt av Berry Smutny mot Aftenposten ble avvist av ankedomstolen i Köln. Domstolens vurdering av erstatning for sakskostnadene er basert på tysk prosessrett. som ikke tilkjenner full erstatning for sakskostnader til en part som har vunnet, men erstatning etter en sjablonmessig utregning. Aftenposten fikk dermed ikke erstattet sine reelle kostnader knyttet til saken i Tyskland.

${ }^{44}$ Roma II-forordningen, artikkel 15 (h).

${ }^{45}$ Se for eksempel Rt. 2009 side 1537 (bokhandlerdommen) og Rt. 2011 side 531 (Bosniadommen). Høyesterett uttaler seg generelt om betydningen av EU-forordningene innenfor internasjonal privatrett i nevnte saker, men er blant annet kritisert for også å gjøre vurderinger som står i motstrid til Roma II-forordningen. Se nærmere om dette i Torstein Frantzen, «Giuditta Cordero-Moss: Internasjonal privatrett på formuerettens område», Lov og Rett, 2014 s. 502 505 (s. 504). 
gjeldende norske prosessregler. Norske parter som anlegger sak ved et forliksråd, må også vurdere utenlandsk prosessrisiko når forliksklagen forkynnes til utenlandsk motpart. I de nevnte tvistene var motparten henholdsvis tysk og engelsk, men den samme problematikken kan oppstå i tvister med motparter fra land med langt mer utfordrende rettssystemer, ineffektiv rettspleie etc. Særlig i det tilfelle Luganokonvensjonen blir harmonisert med Brüsselforordningen og litispendensreglene også skal hensynta behandling av domstoler i tredjestater, jf. fotnote 6 over.

De norske domstoler er ment å utgjøre et hierarki - også forliksrådet inngår her, dog med begrenset domsmyndighet. Det er derfor vanskelig å forstå at den part som følger nødvendige prosessuelle skritt i henhold til norsk rett, skal risikere å miste den rett saksanlegget gir, underveis. Det finnes heller ikke noen reell mulighet for en norsk saksøker til å avskjære litispendensvirkningens opphør, ved for eksempel å ta ut stevning direkte for tingretten. Tingretten vil da henvise saken tilbake til forliksrådet, jf. tvisteloven $\S 4-2$, slik at den samme problemstillingen vil kunne oppstå. Dette stiller norske parter i en uheldig posisjon i noen internasjonale tvister. I forbindelse med kunngjøringen av forliksklagen til utenlandsk motpart vil motparten bli notifisert og sitte igjen med en slags opsjon - enten å la saken gå for norske domstoler eller å ta ut stevning i eget land. Dette er et hensyn $\mathrm{H} \varnothing$ yesterett ikke synes å ha tatt stilling til, og som gjør loven, slik den anvendes i dag, lite rimelig.

\subsection{Litispendens avløses av rettskraft}

I den vanlige læren om rettskraft er litispendens og rettskraft et samlet regelsett som representerer et kontinuerlig hinder mot nye og konkurrerende saker. Grensen trekkes slik at litispendensen opphører når rettskraften inntrer. Det er nettopp dette som er uttalt i tvisteloven § 18-2 annet ledd - virkningen av saksanlegg etter $\$ 18-1$ opphфrer når saken er rettskraftig avgjort.

Etter gjeldende rett opphører litispendensvirkningen i forbindelse med forliksrådets beslutning om innstilling - beslutningen kan ikke påankes og blir rettskraftig umiddelbart. Tvistens materielle sider er imidlertid fortsatt ikke rettskraftig avgjort. Det er ikke noe i forarbeidene som indikerer at rettskraftbegrepet her er så snevert at det bare refererer til muligheten til å anvende rettsmidler mot den formelle avgjørelsen om innstilling som sådan. Riktignok er det slik at spørsmålet om forliksrådet skal behandle saken det nærmeste år, ikke kan påankes, noe som kan sies å være endelig avgjort, jf. tvisteloven § 6-11 (5) og § 19-14. ${ }^{46}$ Tvisteloven § 18-2 annet ledd nevner imidlertid «saken», noe som må innebære en henvisning til den materielle konflikten - når saken er rettskraftig avgjort. Dette fremgår også av forarbeidene, hvor det fremgår at rettskraften innebærer en endelig løsning av det rettsforhold som er oppe til avgjørelse. ${ }^{47}$

Rettsforholdet som aktualiseres i forbindelse med forliksrådets vurdering av om en sak skal innstilles, omfatter spørsmålet om forliksrådet skal behandle noe eller ei, men ikke de materielle spørsmålene som er reist i forbindelse med en aktuell tvist.

Proposisjonens kommentar til bestemmelsen i tvisteloven § 18-2 annet ledd legger dessuten til grunn den tradisjonelle og nokså selvsagte oppfatning om at litispendensbegrepet skal avløses av den materielle rettskraftens negative side:

\footnotetext{
${ }^{46}$ Schei, side 660 .

${ }^{47}$ Ot.prp. nr. 51 (2004-2005) Om lov om mekling og rettergang i sivile tvister (tvisteloven), side 254.
} 
«Annet ledd angir når litispendensvirkningen opphører. Den blir da avløst av rettskraftvirkningen, som vanligvis vil bety en fortsatt og varig hindring for nye søksmål.» ${ }^{48}$

Når disse angivelser av rettskraft og litispendens legges til grunn, ser man at Høyesteretts tolkning av lovbestemmelsene i Rt. 2012 side 1404 innebærer at litispendensvirkningen nettopp ikke opphører når rettskraft inntrer, men på et tidligere stadium. I henhold til Høyesteretts tolkning opphører virkningen når forliksrådet innstiller saken, men før sakens materielle spørsmål er blitt behandlet. Resultatet kan således sies å være i strid med både lovens system og lovgivers generelle intensjon når det gjelder forholdet mellom litispendens og rettskraft, som ikke legger opp til en «dødperiode» mellom litispendensvirkningen og rettskraftvirkningen.

\subsection{Om lovgivers og Høyesteretts oppgave}

Både Høyesterett og Borgarting lagmannsrett har i sine vurderinger av den aktuelle problemstillingen uttalt at det må være lovgivers oppgave å rette opp eventuelle utilsiktede konsekvenser som endringen medfører i internasjonale tvister - dette da det i henhold til proposisjonen synes som om departementet bevisst har gått inn for den aktuelle endringen.

Det foreligger imidlertid ikke noen klare uttalelser i forarbeidene (slik Borgarting lagmannsrett hevder på side $7 \mathrm{i}$ kjennelsen LB-2013-76568 - RG-2013-1193) eller andre indikasjoner på at lovgiver også hadde mulige virkninger i internasjonale tvister $\mathrm{i}$ tankene da fristreglene i den tidligere tvistemålsloven $\S 63$ tredje ledd ble opphevet, jf. avsnitt 3.2. Den mulige følge at etterfølgende saksanlegg i utlandet «rykker frem» i løpet av den tid det tar å bringe saken inn for tingretten, er ikke nevnt noe sted i forarbeidene til tvisteloven. Som angitt over får utenlandske motparter ved gjeldende ordning nærmest en opsjon om valg av verneting ved at en norsk saksøker må anlegge søksmål ved forliksrådet. Om lovgiver hadde ment å innføre en vesentlig forverring for norske parter i internasjonale tvister, burde det ganske visst ha kommet klarere til uttrykk. Det er ingen grunn til at en norsk parts rettsstilling skal avhenge av den tilfeldighet om forliksrådet avsier dom som kan angripes, eller om forliksrådet velger å innstille grunnet sakens kompleksitet. Det er derfor gode grunner til å hevde at den vesentlige svekkelsen av norske parters stilling i internasjonale tvister som foreligger i henhold til dagens praksis, ikke ble vurdert av lovgiver.

Ideelt sett burde lovgiver supplere tvisteloven med en bestemmelse som opprettholder litispendensvirkningen ved forliksrådets innstilling, fortrinnsvis i § 18-2 - slik rettsordningen var før tvisteloven, jf. tvistemålsloven § 63 tredje ledd. Dette vil være i tråd med den alminnelige læren om rettskraft og litispendens som et samlet regelsett til hinder for konkurrerende saker. Det vil heller ikke være i strid med Luganokonvensjonen artikkel 27 og 30, da konvensjonens bestemmelser ikke regulerer når litispendensvirkningen opphører.

Før lovgiver eventuelt endrer lovbestemmelsen, er det imidlertid vanskelig å finne gode argumenter til st $\varnothing t t e$ for Høyesteretts konklusjon. Det er heller relevant å stille spørsmål om $\mathrm{H} \varnothing$ yesteretts passivitet i den videre avklaringen av dette spørsmålet og om $\mathrm{H} \varnothing$ yesterett burde ha tatt en mer aktiv, rettsutviklende rolle. Både formålene med litispendens og reelle hensyn knyttet til virkningene ved dagens tolkning av rettsregelen tilsier at $\mathrm{H} \varnothing$ yesterett burde gjort en annen vurdering. Grunnloven $\S 88$ fastslår at $H \varnothing$ yesterett dømmer i siste instans. Det er ikke bare ment å bety den endelige løsningen i hver enkelt sak, men også den endelige fastleggelse av innholdet av gjeldende rett. Rettsregler skal tolkes slik at formålene med reglene blir fremmet og uønskede virkninger blir søkt unngått - dette innebærer at regler må gis et innhold som er tilpasset

\footnotetext{
${ }^{48}$ Ibid., side 432.
} 
rettssystemet for $\varnothing$ vrig. ${ }^{49} \mathrm{H} \varnothing$ yesteretts I $\varnothing$ sning er ikke tilpasset rettssystemet for $\varnothing$ vrig - verken hva gjelder et hierarkisk domstolsapparat eller prinsippet om litispendens og rettskraft. Høyesterett begrunner hovedsakelig sin løsning med lovens ordlyd. Likevel finnes atskillige avgjørelser fra Høyesterett hvor formål og reelle hensyn har medført et videre tolkningsrom når lovens ordlyd ikke gir noe uttrykkelig svar på et spørsmål. ${ }^{50}$

Det kan også diskuteres hvorvidt det er aktuelt å løse problemet på en annen måte enn ved å endre reglene om litispendens - nemlig ved å oppstille flere unntak fra krav om obligatorisk forliksrådsbehandling i tvisteloven § 6-2 annet ledd, særlig for tilfeller der ingen av partene eller bare én av partene har alminnelig verneting i Norge. I henhold til tvistemålsloven $\S 274$ første ledd nr. 2 var det ikke obligatorisk med forliksrådsbehandling «naar saksøkte eller hans lovlige stedfortræeder ikke har kjendt bopæl, fast arbeidssted eller forretningssted her i riket, og han heller ikke har en fuldmægtig, som har kjendt bopæl her og kan indgaa forlik paa hans vegne.» Unntaket hadde sine klare fordeler i internasjonale tvister hvor kostnadene for utenlandsk parts personlige oppmøte er større og mulighetene for forlik i utgangspunktet kan anses å være mindre. Unntaket ble ikke videreført i tvisteloven, jf. § 6-2 annet ledd. Begrunnelsen for dette er det ikke redegjort for i proposisjonen, og det ble i forarbeidene i begrenset grad vurdert hvilke unntak som burde oppstilles fra hovedregelen om obligatorisk forliksrådsbehandling i tvister om formuesverdier. Denne endringen har tidligere blitt kritisert i Lov og Rett, ${ }^{51}$ dog ikke på bakgrunn av den samme problematikken, om konsekvensene ved litispendensvirkningens opph $\varnothing r$ ved forliksrådets innstilling i internasjonale tvister.

\section{Avslutning}

Den norske forliksrådsfellen gir altså utenlandske motparter et fortrinn i noen internasjonale tvister, og en mulighet til å anlegge sak i en annen stat i forbindelse med forliksrådets forkynnelse og notifisering om rettstvisten. Dette er en forverring av norske parters internasjonale rettsstilling og kommer i tillegg til mulige problemstillinger som allerede foreligger i internasjonale tvister - relatert til forum shopping og den såkalte italienske torpedo-praksisen, ${ }^{52}$ samt harmoniseringen av litispendensreglene i

Brüsselforordningen og Luganokonvensjonen.

Før lovgiver eventuelt endrer tvisteloven, må en norsk part som står overfor forliksrådsbehandling av en tvist med en utenlandsk motpart, være forberedt på utenlandsk rettsprosess - selv etter å ha

49 Jens Edvin A. Skoghøy, «Reelle hensyn som rettskilde», Lov og Rett, 2013 s. 257-258 (s. 258).

${ }^{50}$ Se for eksempel HR-2016-01769-U, avsnitt 12-14, Rt. 2012 side 1951, Rt. 2012 side 1985, Rt. 2010 side 291 og Rt. 2010 side 691.

${ }^{51}$ Andreas Nordby, Ole Andenæs og Borgar Høgetveit Berg, «Tvisteloven - ti på topp og ti på bunn», Lov og Rett, 2012 s. 3-22 (s. 18).

52 «Italian Torpedo»- det å anlegge en lignende rettssak i hjemstaten eller i en tredje stat med årelang og ineffektiv rettspleie kun med det formål å trenere rettsprosessen. Teoretisk sett kan slik torpedering føre til at norske parter gir opp sine krav, alternativt inngår ufordelaktige forlik kun for å få avsluttet saken. EU-domstolen har i Erich Gasser BmbH v. MISAT Srl. (Case 116/02 Gasser v MISAT [2003] European Court Reports I-14693) slått fast at litispendensregelen i Brüsselforordningen gjelder uansett lengden av nasjonale rettsprosesser, mens EMD allerede i 1999 hadde avgjort 65 saker hvor italienske domstoler bryter EMK art. 6 nr. 1 i forbindelse med ineffektive og lange rettsprosesser (EMDs dom 28. juli 1999 Ferrari $v$ Italy, avsnitt 21). Gjeldende norske ordning gir utenlandske motparter en slik mulighet til å torpedere saken. Dette er problemstillinger og realiteter i internasjonale tvister som Høyesterett ikke har drøftet i sin avgjørelse. 
vært først ute ved å ta ut forliksklage i Norge. Ordningen kan medføre utfordringer og merkostnader for norske parter. Denne prosessuelle usikkerhet er verken hensiktsmessig, forutsigbar eller tilsiktet i et norsk perspektiv. 